wheat stalk, are arranged in the following order: sunflower, buckwheat, sorghum, safflower, soybean, mustard, flax, oats, rape, barley, peas, wheat. Grain germination in corn and rye stalks did not affect the length of soft wheat stalks.

Key words: allelopathy, soft wheat, germination energy, germination, seedling vigor, stalk length

\title{
ФОРМУВАННЯ ЯКОСТІ ХЛІБА 3 БОРОШНА ПШЕНИЦІ СПЕЛЬТИ
}

\author{
В. Б. КОВАЛЬОВ, доктор сільськогосподарських наук \\ О. І. ТРЕМБІЦЬКА, кандидат сільськогосподарських наук \\ Т. В. КЛИМЕНКО, кандидат сільськогосподарських наук \\ С. В. ФЕДОРЧУК, кандидат сільськогосподарських наук \\ Ю. Л. ПЕТУХОВ, аспірант \\ Поліський національний університет
}

У статті представлено результати визначення показників якості хліба з обойного борошна пшениці спельти. 3'ясовано, щэо хліб, випечений з обойного борошна пшениці спельти, мав кращий зовнішній вигляд, правильну форму $i$ більш виражені смакові властивості. Зерно пшениці спельти сорту Європа, який є результатом гібридизаџіï Triticum aestivum / Triticum spelta, nоступалось якісним показникам сорту Зоря України.

Ключові слова: пшениия спельта, пшениия м'яка, білок, клейковина, хліб, кулінарна якість хліба.

Зерно пшениці забезпечує близько 20 \% загального споживаного протеїну [1]. Нині впроваджуються у виробництво малопоширені iї види. Одним із перспективних таких є пшениця спельта (Triticum spelta L.) [2]. У зерні цього виду майже ідеально поєднанні необхідні для людського організму вітаміни, мінеральні елементи й амінокислоти. Зерно містить полісахариди, які здатні зміцнювати імунну систему [3]. Корисні речовини, які містяться в пшениці спельти, мають високий рівень розчинності, тому вони легко і швидко засвоюються організмом [4]. Крім цього, пшениця спельта добре росте в умовах низького вмісту азоту в грунті, тому є цінною культурою для органічного землеробства, в тому числі в зоні Полісся, і може бути джерелом органічного, здорового і безпечного продукту харчування [5].

Аналіз останніх досліджень і публікацій. Вміст білка в зерні пшениці спельти зазвичай змінюється від 12,5 до 18,4\%, але сильно залежить від агротехнології та грунтово-кліматичних умов [6]. Проте були дослідження, в яких отримували зерно пшениці спельти з вмістом білка від 7,5 до 19,5 \% [7]. Пшениця спельта відрізняється від пшениці кількістю та типом білків зерна, 
особливо проламінів. Це може бути причиною того, що деякі люди з харчовою алергією можуть переносити продукти, що містять спельту [1].

Що стосується використання зерна пшениці спельти у вигляді хлібобулочних виробів, реологічні властивості тіста представляють великий інтерес. Повідомляється, що пшениця спельта формує тісто 3 меншою стійкістю, еластичністю та більшою розтяжністю, ніж пшеничне. Це обгрунтовано, оскільки у реологічних властивостях клейковини із пшениці спельти переважають гліадини, тоді як у клейковини пшениці м'якої глютеніни [8]. Завдяки цьому маніпуляції з тістом пшениці спельти складніші через його м'якість і липкість після замішування [9]. Крім цього, вищий вміст волокна в зерні негативно впливає на реологію тіста та якість хліба [10]. Зерно пшениці спельти зазвичай використовують для виробництва хліба, печива та бісквіта, макаронних виробів і національних страв [11]. Для виготовлення хліба iз пшениці спельти потрібно застосовувати модифіковану технологію. Наприклад, у випадку 3 хлібом рекомендується збільшене добавляння аскорбінової кислоти, зменшення часу замісу, зменшення добавляння води, тривалості бродіння тіста, а для макаронних виробів пропонується високотемпературне сушіння [12]. Нині розроблено технології перероблення зерна пшениці спельти у круп'яні продукти $[13,14]$. Технологічні режими при цьому достовірно відрізняються від відомих [15]. Більшість робіт з дослідження перероблення зерна пшениці спельти проводились у напрямку виробництва круп, проте основну частину продуктів харчування із зерна пшениці становлять хлібобулочні вироби. Тому дослідження щодо формування якості хліба 3 борошна пшениці спельти $\epsilon$ актуальними.

Методика досліджень. Для досліджень було взято зерно пшениці спельти озимої сорів Зоря України та Свропа, вирощене за загальноприйнятою для зони Полісся агротехнологією. Проводили визначення основних технологічних показників якості згідно методик державних стандартів у лабораторії кафедри технології зберігання та переробки продукції рослинництва та лабораторії ДП «Полтавастандартметрологія». У дослідженнях використовували обойне борошно пшениці. Визначення вмісту білка проводили за методом К'єльдаля. Визначені хлібопекарські якості борошна із зерна пшениці спельти порівнювали із зерном пшениці м'якої сорту Дарунок Поділля. Рецептура хліба включала добавляння до 550 г борошна $400 \mathrm{~cm}^{3}$ води, 20,8 г дріжджів, 12,5 г цукру та 7,2 г кухонної солі. Для статистичного оброблення результатів досліджень і визначення достовірності одержаних експериментальних даних використовували пакет стандартних програм (ПІК «Agrostat», MSOfficeExcel).

Результати досліджень. Для використання зерна на харчові цілі важливе значення мають запасні білки, які в пшениці зумовлюють хлібопекарські властивості борошна. Ці запасні білки: проламіни і глютеліни утворюють клейковину, яка відіграє першочергову роль у хлібопекарській і макаронній промисловості, утворюючи структуру виробу [16]. Одним 3 основних показників якості зерна пшениці, що має безпосередній вплив на хлібопекарські 
властивості, $є$ вміст клейковини. Високий вміст клейковини не лише поліпшує харчову цінність хліба, а $\epsilon$ основною умовою доброї хлібопекарської якості борошна і значною мірою зумовлює об'ємний вихід хліба, відношення між висотою череневого хліба і його діаметром, пористість і зовнішній вигляд. Від кількості клейковини і ії якості в основному залежать реологічні властивості тіста [17].

Пшениця спельта порівняно з сучасними сортами пшениці м'якої містить на 12-21\% більше білка, багата рослинними харчовими волокнами, високоякісними жирами. Так, у проведених дослідженнях у 2018-2019 рр. в умовах Брусилівського району на бідних піщаних грунтах це твердження було підтверджено (табл. 1).

Табл. 1. Вміст білка та клейковини у зерні залежно від сорту (2018-2019 pp.), \%

\begin{tabular}{|l|c|c|}
\hline Сорт & Вміст білка & Вміст клейковини \\
\hline Дарунок Поділля (контроль) & 11,2 & 19,4 \\
\hline Зоря України & 18,2 & 36,3 \\
\hline Свропа & 14,5 & 27,8 \\
\hline$H I P_{05}$ & 0,8 & 1,5 \\
\hline
\end{tabular}

Найвищий вміст клейковини був виявлений у зерні пшениці спельти Зоря України - 36,3\% або на 16,8 \% вище від пшениці м'якої сорту Дарунок Поділля, яка в умовах Брусилівського району за інтенсивної технології вирощування належала до 1-3 класів на низькородючих грунтах. Навіть більше - такий високий вміст клейковини не притаманний навіть для сильних пшениць. Сорт Європа мав значно менший вміст клейковини - 27,8\% або на $8 \%$ більше від контролю.

Якість хліба 3 пшениці спельти значно відрізнялась від пшениці м'якої. Так, хліб з борошна пшениці спельти сорту Зоря України мав правильну опуклу форму і колір, тоді як з борошна пшениці Дарунок Поділля тісто не трималось форми, мало рвану увігнуту поверхню і блідий з сірим відтінком колір (табл. 2).

Табл. 2. Зовнішній вигляд хліба з борошна пшениць, 2018-2019 рр.

\begin{tabular}{|l|c|c|c|c|c|c|}
\hline \multirow{2}{*}{ Сорт } & \multicolumn{4}{|c|}{ Зовнішній вигляд хліба } \\
\cline { 2 - 8 } & \multicolumn{2}{|c|}{ поверхня } & \multicolumn{3}{|c|}{ форма } & \multicolumn{2}{|c|}{ забарвлення скоринки } \\
\cline { 2 - 8 } & бал & & бал & & бал & \\
\hline $\begin{array}{l}\text { Дарунок } \\
\text { Поділля }\end{array}$ & 1 & рвана & 1 & увігнута & 2 & $\begin{array}{c}\text { бліде з сірим } \\
\text { відтінком }\end{array}$ \\
\hline $\begin{array}{l}\text { Зоря } \\
\text { України }\end{array}$ & 4 & рівна & 5 & куполоподібна & 4 & світло-коричневе \\
\hline Європа & 2 & $\begin{array}{c}\text { 3 мілкими } \\
\text { тріщинами }\end{array}$ & 3 & напівовальна & 4 & світло-коричневе \\
\hline НІР $_{05}$ & 1 & - & 1 & - & 1 & - \\
\hline
\end{tabular}


Хліб з борошна спельти сорту Європа порівняно 3 хлібом сорту Зоря України мав дещо гірший зовнішній вигляд - напівовальна 3 мілкими тріщинами поверхня світло-коричневого кольору.

Найвищу оцінку показників зовнішнього вигляду хліба отримано 3 борошна пшениці спельти сорту Зоря України - 4-5 бала, найнижчу - у пшениці м'якої - 1-2 бала. Цей показник у пшениці спельти сорту Європа був на рівні 2-4 бала.

М'якуш хліба всіх пшениць мав крупну рівномірну, проте товстостінну пористість або 2 бала відповідно до шкали оцінювання (табл. 3).

Табл. 3. Характеристика м'якуша хліба пшениць, 2018-2019 рр.

\begin{tabular}{|l|c|c|c|c|c|}
\hline \multirow{2}{*}{ Сорт } & \multicolumn{2}{|c|}{ Пористість } & \multicolumn{2}{|c|}{ Еластичність } & $\begin{array}{c}\text { Забарвлення } \\
\text { м'якуша }\end{array}$ \\
\cline { 2 - 6 } & бал & & бал & & Темне \\
\hline $\begin{array}{l}\text { Дарунок } \\
\text { Поділля }\end{array}$ & 2 & $\begin{array}{c}\text { Крупна, рівномірна, } \\
\text { товстостінна }\end{array}$ & 1 & $\begin{array}{c}\text { Мало } \\
\text { еластичний }\end{array}$ & Темне \\
\hline $\begin{array}{l}\text { Зоря } \\
\text { України }\end{array}$ & 2 & $\begin{array}{c}\text { Крупна, рівномірна, } \\
\text { товстостінна }\end{array}$ & 5 & Еластичний & Брудно-жовте \\
\hline Свропа & 2 & $\begin{array}{c}\text { Крупна, рівномірна, } \\
\text { товстостінна }\end{array}$ & 5 & Еластичний & - \\
\hline НІР $_{05}$ & 1 & - & 1 & - & - \\
\hline
\end{tabular}

Еластичність найвищою була в хліба, отриманого 3 пшениці спельти 5 бала, а в пшениці м'якої він був на рівні 1 бала. Колір м'якуша хліба 3 пшениці м'якої та пшениці спельти сорту Зоря України був темний, а в сорту Європа - брудно жовтий, що зумовлено використанням у рецептурі обойного борошна. Між вмістом білка в зерні та еластичністю м'якуша встановлено прямий високий кореляційний зв'язок $(\mathrm{r}=0,82 \pm 0,007)$. Очевидно, що вищу кулінарну якість хліба у пшениці спельти отримано завдяки його вмісту.

Отже, пшениця спельта може використовуватись для виробництва хліба 3 обойного борошна. Слід відзначити, що він має вищу біологічну цінність завдяки більшому вмісту білка в зерні. Новий сорт пшениці спельти Європа значно легше вимолочується порівняно з сортом Зоря України, що $є$ основною проблемою цієї культури при іiі переробці, проте поступається якісними показниками за однакових грунтово-кліматичних умов.

Висновки. За однакових умов вирощування пшениця м'яка сорту Дарунок Поділля значно поступалась пшениці спельті. Хліб, випечений 3 обойного борошна пшениці спельти, мав кращий зовнішній вигляд, правильну форму і більш виражені смакові властивості. Зерно пшениці спельти сорту Європа, який є результатом гібридизації Triticum aestivum / Triticum spelta, поступалось якісним показникам сорту Зоря України. 


\section{Лiтература}

1. Kucek L., Veenstra L., Amnuaycheewa P., Sorrells M. A grounded guide to gluten: how modern genotypes and processing impact wheat sensitivity. Comprechens. Rev. Food. Sci. Food Safety, Inst. Food Technol. 2015. Vol. 14. P. 285-302.

2. Пшениця спельта / Г. М. Господаренко, П. В. Костогриз, В. В. Любич та ін.; за заг. ред. Г. М. Господаренка. Київ: ТОВ «СІК ГРУП УКРАЇНА». 2016. $312 \mathrm{c}$.

3. Любич В. В. Біологічна цінність білка пшениці спельти залежно від походження сорту та лінії. Зб. наук. пр. Уманського НУС. 2016. Вип. 89. С. 199206.

4. Любич В. В. Хлібопекарські властивості зерна сортів пшениці озимої залежно від видів, норм і строків застосування азотних добрив. Вісник Дніпропетровського ДАЕУ. 2017. № 2. С. 35-41.

5. Парій Ф. М., Сухомуд О. Г., Любич В. В. Оцінка господарсько-цінних властивостей нового сорту пшениці спельти озимої Зоря України. Насінництво. 2013. № 5 (125). C. 5.

6. Любич В. В. Круп'яні властивості зерна пшениці м'якої озимої залежно від сорту. Вісник Харківського національного технічного університету сільського господарства імені Петра Василенка. 2019. № 2. С. 94-101.

7. Kohajdova Z., Karovicova J. Effect of incorporation of spelt flour on the dough properties and wheat bread quality. Zywnosc. Nauka. Technol. Jakosc. 2007. Vol. 4 (53). P. 36-45.

8. Pruska-Kedzior A., Kedzior Z., Klockiewicz-Kaminska E. Comparison of viscoelastic properties of gluten from spelt and common wheat. Eur. Food Res. Technol. 2008. Vol. 227. P. 199-207.

9. Zanetti S., Winzeler M., Feullet C., Keller B., Messner M. Genetic analysis of bread-making quality in wheat and spelt. Plant Breed. 2001. Vol. 120. P. 13-19.

10. Escarnot E., Agneessens R., Wathelet B., Paquot M. Quantitative and qualitative study of spelt and wheat fibres in varying milling fractions. Food Chem. 2010. Vol. 122. P. 857-863.

11. Abdel-Aal E.-S.M., Rabalski I. Effect of baking on nutritional properties of starch in organic spelt whole grain products. Food Chem. 2008. Vol. 111. P. 150156.

12. Schober T.J., Bean S.R., Kuhn M. Gluten proteins from spelt (Triticum aestivum ssp. spelta) cultivars: a rheological and size-exclusion high-performance liquid chromatography study. J. Cereal Sci. 2006. Vol. 44. P. 161-173.

13. Любич В. В., Полянецька І. О. Якість цілої крупи із зерна спельти залежно від індексу його лущіння та водно-теплової обробки. Вісник Уманського НУС. 2015. № 2. Р. 34-38.

14. Господаренко Г. М., Любич В. В., Полянецька І. О. Вихід і якість круп'яних продуктів із зерна сортів і ліній пшениць. Вісник полтавської державної аграрної академії. 2017. Вип. 4. С. 11-17. 
15. Господаренко Г. М., Полторецький С. П., Любич В. В., Желєзна В. В. Удосконалення режимів пропарювання за виробництва крупи плющеної із зерна пшениці спельти. Збірник наукових праиь НУС. 2018. Вип. 93(1). С. 8-22.

16. Господаренко Г. М., Любич В. В., Полянецька I. О., Возіян В. В. Хлібопекарські властивості зерна спельти залежно від удобрення. Вісник Уманського НУС. 2015. № 1. С. 11-16.

17. Любич В. В. Хлібопекарські властивості зерна сортів пшениці озимої залежно від видів, норм і строків застосування азотних добрив. Вісник Дніпропетровського ДАЕУ. №2. 2017. С. 35-41.

\section{References}

1. Kucek, L., Veenstra, L., Amnuaycheewa, P., Sorrells, M. (2015). A grounded guide to gluten: how modern genotypes and processing impact wheat sensitivity. Rev. Food. Sci. Food Safety, Inst. Food Technol, no. 14, pp. 285-302.

2. Hospodarenko, G.M., Kostogryz, V.P., Liubych, V.V. (2016). Wheat spelt. Kyiv: SIK GROUP UKRAINE, 312 p. (in Ukrainian).

3. Liubich, V.V. (2016). Biological value of spelt wheat protein depending on the origin of the variety and strain. Bulletin of Uman NUH, no. 89, pp. 199-206 (in Ukrainian).

4. Liubich, V.V. (2017). Bread properties of grain of winter wheat varieties depending on types, norms and terms of application of nitrogen fertilizers. Bulletin of Dnipropetrovsk State Economic University, 2017, no. 2, pp. 35-41. (in Ukrainian).

5. Pariy, F.M., Sukhomud, O.G., Lyubich, V.V. (2013). Estimation of economically valuable properties of a new variety of winter spelled wheat Zorya Ukrainy. Seed production, no. 5 (125). pp. 5. (in Ukrainian).

6. Liubych, V. V. Cereal properties of grain of bread wheat depending on the variety. Bulletin of the Kharkov National Technical University of Agriculture name Petr Vasilenko, 2019, no. 2, pp. 94-101. (in Ukrainian).

7. Kohajdova, Z., Karovicova, J. (2007). Effect of incorporation of spelt flour on the dough properties and wheat bread quality. Zywnosc. Nauka. Technol. Jakosc, no. 4 (53), pp. 36-45.

8. Pruska-Kedzior, A., Kedzior, Z., Klockiewicz-Kaminska, E. (2008). Comparison of viscoelastic properties of gluten from spelt and common wheat. Eur. Food Res. Technol, no. 227, pp. 199-207.

9. Zanetti, S., Winzeler, M., Feullet, C., Keller, B., Messner, M. (2001). Genetic analysis of bread-making quality in wheat and spelt. Plant Breed., no. 120, pp. 1319.

10. Escarnot, E., Agneessens, R., Wathelet, B., Paquot, M. (2010). Quantitative and qualitative study of spelt and wheat fibres in varying milling fractions. Food Chem., no. 122, pp. 857-863.

11. Abdel-Aal, E.-S.M., Rabalski, I. (2008). Effect of baking on nutritional properties of starch in organic spelt whole grain products. Food Chem., no. 111, pp. $150-156$. 
12. Schober, T.J., Bean, S.R., Kuhn, M. (2006). Gluten proteins from spelt (Triticum aestivum ssp. spelta) cultivars: a rheological and size-exclusion highperformance liquid chromatography study. J. Cereal Sci., no. 44, pp. 161-173.

13. Liubych, V. V., Polyanetska, I. O. (2015). Quality of cereals grain of spellt wheat depending on the index its unhusking and water-heat processing. Bulletin of Uman NUH, no. 2, pp. 34-38. (in Ukrainian).

14. Hospodarenko, H. M., Liubych, V. V., Polyanetskaya, I. O. (2017). Output and quality of cereal products from wheat varieties and wheat lines. Bulletin of poltava state agrarian academy, no. 4, pp. 11-17. (in Ukrainian).

15. Hospodarenko, G. M., Poltoretskyi, S. P., Liubych, V. V., Zheliezna, V. V. (2018). Improvement of the parcooking mode for the rolled groats production of spelt wheat. Collected Works of Uman NUH, no. 93(1), pp. 8-22.

16. Hospodarenko, G.M., Lyubich, V.V., Polyanetska, I.O., Voziyan, V.V. (2015). Baking properties of spelled grain depending on fertilizer. Bulletin of Uman NUS, no. 1. pp. 11-16. (in Ukrainian).

17. Liubich, V.V. (2017). Bread properties of grain of winter wheat varieties depending on types, norms and terms of application of nitrogen fertilizers. Bulletin of Dnipropetrovsk State Economic University, no. 2, pp. 35-41 (in Ukrainian).

\section{Аннотация}

\section{Ковалев В. Б., Трембицкая О.И., Клименко Т.В., Федорчук С. В., Петухов Ю. Л. \\ Формирование качества хлеба с муки пиеницы спельты}

Одной из наиболее важных проблем человечества остается продовольственная, в частности увеличение количества аллергиков и снижение показателей пищевых качеств и безопасности продуктов питания.

Цель. Изучить вопрос о формировании качества хлеба из муки пшениць спельты в условиях Полесья.

Методы. Лабораторные, математико-статистические, физикохимические.

Результаты исследований. Пшенииа спельта по сравнению $c$ современными сортами пшенищы мягкой содержит на 12-21 \% больше белка. Так, при проведении исследований в 2018-2019 г2. В условиях Брусиловского района на бедных песчаных почвах это утверждение было подтверждено. Качество хлеба из пшениць спельты значительно отличалась от пшениць мягкой. Так, хлеб из муки пшеницы спельты сорта Заря Украины имел правильную выпуклую форму, тогда как из муки пшениць Подарок Подолья тесто не держалось формы, мало рваную вогнутую поверхность и бледный с серым оттенком ивет. Хлеб из муки спельты сорта Европа по сравнению с хлебом сорта Заря Украины имел несколько хуже внешний вид - полуовальная с мелкими трещиинами поверхность светло-коричневого ивета. Наивысшую оченку показателей внешнего вида хлеба получено из муки пшенищы спельты сорта Заря Украине - 4-5 балла, самую низкую - в пшенице мягкой - 1-2 балла. Этот показатель у пшеницы спельты сорта Европа был на уровне 2-4 балла. Мякиш хлеба всех пшении имел крупную равномерную, однако толстостенную пористость или 2 балла в соответствии со шкалой оценки. Эластичность 
высокой была в хлеба, полученного из пшеницы спельты - 5 балла, а в пшенице мягкой он был на уровне 1 балла. Цвет мякоти хлеба из пшеницы мягкой и пшеницы спельты сорта Заря Украине был темный, а в сорта Европа желтый, что обусловлено использованием в рецептуре обойной муки. Между содержанием белка в зерне и эластичностью мякоти установлена прямая высокая коррелячиионная связь $(r=0,82 \pm 0,007)$. Очевидно, что высшее кулинарное качество хлеба в пшенице спельты получено благодаря его содержимого.

Выводы. При одинаковых условиях выращивания пшеница мягкая сорта Подарок Подолья значительно уступала пшенице спельте. Хлеб, выпеченный из обойной муки пшеницы спельты, имел лучший внешний вид, правильную форму и более выражены вкусовые свойства. Зерно пшенищы спельты сорта Европа, который является результатом гибридизации Triticum aestivum/Triticum spelta, уступало качественным показателям сорта Заря Украины.

Ключевые слова: пшеница спельта, пшеница мягкая, белок, клейковина, хлеб, кулинарное качество хлеба

\section{Annotation}

\section{Kovalev V. B., Trembitskaya O. I., Klimenko T. V., Fedorchuk S. V., Petukhov Yu. L. Quality formation of spelt wheat flour bread}

One of the most important problems of mankind remains food, the increase in the number of allergy sufferers and the reduction of food quality and food safety, in particular. Polissia.

Aim. To study the issues of forming the quality of spelt wheat flour bread in

Methods. Laboratory, mathematical and statistical, physico-chemical.

Results. Spelt wheat contains 12-21\% more protein than modern varieties of soft wheat. Thus, when conducting research in 2018-2019 under Brusyliv district conditions on poor sandy soils, this statement was confirmed. The quality of spelt wheat bread differed significantly from that of soft wheat. Thus, Zoria Ukrainy spelt wheat bread had the correct convex shape and colour, while Darunok Podillia wheat flour did not keep its shape, had a torn concave surface and a pale grey colour. Compared to Zoria Ukrainy bread, bread made from Europe variety spelt flour had a slightly worse appearance - a light brown semi-oval surface with small cracks. The highest score on bread appearance was obtained from Zoria Ukrainy spelt wheat flour - 4-5 points, the lowest - from soft wheat - 1-2 points. This indicator of Europe variety spelt wheat was at the level of 2-4 points. The bread crumb of all wheat varieties had a large uniform but thick-walled holes or 2 points according to the rating scale. The highest bread softness was obtained from spelt wheat bread5 points, and in soft wheat it was at the level of 1 point. The bread crumbs colour of soft wheat and Zoria Ukrainy spelt wheat was dark, and of Europe variety - dirty yellow due to the use of wallpaper flour in the recipe. There is a direct high correlation between the grain protein content and the bread softness ( $r=$ $0.82 \pm 0.007)$. It is obvious that the highest culinary quality of spelt wheat bread is obtained due to its content.

Conclusions. Under the same growing conditions, Darunok Podillia soft wheat was significantly inferior to spelt wheat. Bread baked from spelt wheat wallpaper 
flour had a better appearance, the correct shape and more pronounced taste. Europe spelt wheat grain, which is the result of Triticum aestivum/Triticum spelta hybridization, was inferior to the quality indicators of Zoria Ukrainy variety. bread

Key words: spelt wheat, soft wheat, protein, gluten, bread, bakery quality of

\title{
КОРМОВА ЦННІСТЬ ЗЕЛЕНОЇ МАСИ СУМІШОК ЛЯДВЕНЦЮ РОГАТОГО І ЗЛАКОВИХ БАГАТОРІЧНИХ ТРАВ ЗАЛЕЖНО ВІД РЕЖИМУ ВИКОРИСТАННЯ
}

\author{
В. О. ОЛІФІРОВИЧ, кандидат сільськогосподарських наук \\ Буковинська державна сільськогосподарська дослідна станція \\ Інституту сільського господарства Карпатського регіону НААН \\ О. С. ЧИНЧИК, доктор сільськогосподарських наук \\ Подільський державний аграрно-технічний університет \\ В. С. КРАВЧЕНКО, кандидат сільськогосподарських наук \\ Л. В. ВИШНЕВСЬКА, кандидат сільськогосподарських наук \\ Я. О. ЯРОВИЙ \\ Уманський національний університет садівництва
}

У статті наведено результати досліджень з визначення впливу складу травосумішок $i$ режиму використання на кормову цінність травостою, зокрема, вміст у сухій речовині кормових одиниць, сирого протеїну, валової та обмінної енергії. Встановлено, щзо за триукісного режиму використання лядвенцево-злакових травостоїв поживність корму була вищою, порівняно $з$ проведенням двох укосів. А найвищу кормову ијінність мала зелена маса із сумішки лядвенцюю рогатого з тимофї̈вкою лучною.

Ключові слова: лядвенець рогатий, злакові трави, режими використання, кормові одиниці, сирий протеїн, обмінна енергія.

Постановка проблеми. Основним орієнтиром для сучасного кормовиробництва повинна стати інноваційна модель розвитку, яка забезпечуватиме виробництво кормів із заданими параметрами якості [1]. Однак якісні показники сіна багаторічних трав досить варіабельні і залежать від складу травосумішей, укосу, строків збирання та кліматичних умов років вирощування [2].

Аналіз останніх досліджень і публікацій. Багаторічні бобові трави слугують основним джерелом протеїну для тваринництва [3]. Так, використання травостою лядвенцю рогатого, вирощеного на антропогенно перетворених грунтах із застосуванням помірних доз мінеральних добрив забезпечує отримання корму, що характеризується високою поживністю [4]. 